\title{
CONTROL BY OVARIAN HORMONES OF THE INFLAMMATORY RESPONSE IN THE SHEEP UTERUS*
}

\author{
T. H. BRINSFIELD, H. W. HAWK AND E. C. LEFFEL \\ Animal Husbandry Research Division, Agricultural Research Center, \\ Beltsville and Department of Animal Science, University of Maryland, \\ College Park, Maryland, U.S.A.
}

(Received 20th December 1962)

\begin{abstract}
Summary. Oestrous, luteal-phase and ovariectomized ewes were inoculated in the uterine lumen with Escherichia coli and killed 2, 4, 8 or $16 \mathrm{hr}$ later. Intense leucocytic responses and closely associated bactericidal activity occurred within $4 \mathrm{hr}$ in ovariectomized ewes, within $8 \mathrm{hr}$ in oestrous ewes and within $16 \mathrm{hr}$ in luteal-phase ewes. Intense leucocytic emigration was inhibited for 2 to $3 \mathrm{hr}$ in oestrous ewes and considerably longer in luteal-phase ewes. No evidence was found that hormones inhibited the passage of extravasated leucocytes through endometrial stroma.

The incubation of $E$. coli in excised uteri failed to indicate that non-cellular bactericidal factors were normally present in uterine lumens of ovariectomized ewes.
\end{abstract}

\section{INTRODUCTION}

Ovarian hormones have been shown to modify the leucocytic response to experimental infection in the uterine lumen (McDonald, Black, McNutt \& Casida, 1952; Black, Ulberg, Kidder, Simon, McNutt \& Casida, 1953a; Black, Simon, McNutt \& Casida, 1953b; Rowson, Lamming \& Fry, 1953). Rowson et al. (1953) and Black, Simon, Kidder \& Wiltbank (1954) found that uterine bactericidal action was more efficient in oestrous rabbits and cows than in luteal-phase ones. Uteri of these animals were examined 1 to 2 days after the induction of infection.

Later studies showed that ovarian hormones influenced the leucocytic response during the first few hours of induced infection in the rabbit uterus; the response was delayed in progestin-influenced rabbits and hastened and intensified in oestrogen-influenced ones (Hawk, 1958; Broome, Lamming \& Smith, 1959b; Hawk, Turner \& Sykes, 1960a; Heap, Robinson \& Lamming, 1962). Intense bactericidal activity was associated with the influx of neutrophilic leucocytes into the uterine lumen.

Sheep have also shown earlier responses to experimental uterine infection during oestrus than during the luteal phase (Hawk, Turner \& Sykes, 1961a). However, the leucocytic response was slower in oestrous ewes than was found

* These data are taken from a thesis submitted by the senior author to the Graduate School, University of Maryland, as part of the requirements for the degree of Master of Science. 
previously in oestrous rabbits, suggesting possible species differences in endocrine effects on the uterine inflammatory response. The present study was conducted to compare leucocytic responses in uteri of oestrous and luteal-phase ewes to that in ovariectomized ewes, to relate leucocytic responses to uterine bactericidal activity and to look for evidence of hormonal effects on the rate of leucocytic passage through the endometrium.

\section{MATERIALS AND METHODS}

The experimental design was a $3 \times 4$ factorial replicated five times. The sixty ewes were classified by endocrine state (oestrous, luteal-phase or ovariectomized) and by time examined after uterine inoculation $(2,4,8$ or $16 \mathrm{hr})$.

The ewes were Hampshire-Rambouillet crossbreds. They were approximately 1 year of age, with the exception of six older ewes used in one replicate. Ewes were checked for oestrus daily by the use of vasectomized rams. Aprons were used on the rams to prevent copulation, since it was desired that seminal fluids should not be present in uteri of oestrous ewes. The oestrous ewes were in heat at the time of use. Luteal-phase ewes were used 7 or 8 days after oestrus. Ovariectomized ewes were used 3 to 4 weeks after both ovaries were removed through a flank incision; each ewe had shown several oestrous cycles prior to ovariectomy.

At the time of uterine inoculation, each ewe was anaesthetized with pentobarbital sodium and laparotomized midventrally. A thread was passed through the intercornual ligament and tied around one uterine horn anterior to the body of the uterus. A small incision was made at the tubo-uterine junction of the ligated horn, a blunt needle was passed into the uterine lumen and $1 \mathrm{ml}$ of Escherichia coli suspension was injected into the lumen. A ligature was tightened around the tip of the uterine horn as the needle was withdrawn. The horn was ligated to prevent drainage of the inoculum through the cervix or oviduct. Only one uterine horn of each ewe was inoculated. The oestrous, luteal-phase and ovariectomized ewes in each within-replicate time group were inoculated within a few minutes of one another with the same $E$. coli suspension.

Inocula were prepared by washing 24-hr cultures of $E$. coli from trypticase soy agar slopes with sterile saline solution $(0.87 \% \mathrm{NaCl})$ and diluting to a standard turbidity. The mean inoculum was $717,000,000$ bacteria per ewe. The number of $E$. coli in the inoculum was determined by colony counts in violet red bile agar.

Twenty minutes before the ewes in four replicates were killed, each was given an intravenous injection of trypan blue dye to study uterine vascular permeability (Hawk, Brinsfield \& Righter, 1963a).

The animals were killed 2, 4, 8 or $16 \mathrm{hr}$ after inoculation and the uteri removed immediately. Sterile saline solution was injected aseptically into the lumen of each inoculated horn through a seared area on the serosa. Each horn was manipulated to suspend bacteria and leucocytes in the saline solution. The horn was drained of its contents, then flushed with additional saline solution. The total volume of flushings was recorded. Serial dilutions were made of the flushings, and duplicate 1-ml aliquots of each dilution were plated in 
violet red bile agar. After incubation of the plates for 18 to $24 \mathrm{hr}$ at $37^{\circ} \mathrm{C}$, the $E$. coli colonies were counted and calculations made of the number of $E$. coli flushed from each inoculated horn.

Several $0.01 \mathrm{ml}$ samples of the flushings from each horn were spread over a circular area $1 \mathrm{~cm}$ in diameter on a glass slide, air-dried and stained with methylene blue for microscopic examination. The flushings were centrifuged at $100 \mathrm{~g}$ for $20 \mathrm{~min}$ and the volume of cellular debris recorded.

The numbers of leucocytes in flushings of the 2-hr and 4-hr ewes were calculated from counts obtained in microscopic sweeps through the circles of stained flushings. In 8-hr and 16-hr ewes the packed cell volume of leucocytes in centrifuged flushings was usually sufficient to estimate the numbers $(0 \cdot 1 \mathrm{ml}$ of debris $\simeq 160,000,000$ leucocytes).

Specimens from both the inoculated and uninoculated horns of each ewe were fixed in Bouin's solution, cut at $9 \mu$ and stained with haematoxylin and eosin. The degree of leucocytic infiltration of the endometrium was graded on a scale from 0 (no leucocytic response) to 9 (extreme tissue leucocytosis). Several sections from each specimen were examined.

The data were examined statistically by analysis of variance; subclass means were compared by the Duncan multiple range test (Duncan, 1955). The numbers of leucocytes and $E$. coli flushed from each ewe were converted to logarithmic numbers for statistical analysis. The mean log number for each group and its corresponding antilog is given (Table 1).

\section{RESULTS}

\section{LEUCOGYTIC RESPONSES}

Ewes of the three endocrine states showed marked and consistent differences in the rate of leucocytic response to uterine inoculation. The response was fastest in ovariectomized ewes, intermediate in oestrous ewes and slowest in luteal-phase ewes. Analysis of variance showed a significant interaction between endocrine state and time for both tissue leucocytosis and numbers of luminal leucocytes $(P<0 \cdot 01$ for each analysis $)$.

Uninoculated uterine horns were not infiltrated by polymorphonuclear leucocytes; each horn had a score of 0 for tissue leucocytosis on a scale from 0 to 9 .

At $2 \mathrm{hr}$ after inoculation the mean indexes of leucocytic infiltration of inoculated horns were $4 \cdot 0,2.4$ and 1.6 for ovariectomized, oestrous and lutealphase ewes, respectively (Table 1 ). The extreme values differed significantly $(P<0 \cdot 05)$. Few leucocytes had entered the uterine lumens.

By $4 \mathrm{hr}$ after inoculation the mean indexes of endometrial leucocytosis were $6 \cdot 8,4 \cdot 4$ and $2 \cdot 4$ for ovariectomized, oestrous and luteal-phase ewes; the extreme values again differed significantly $(P<0 \cdot 01)$. More importantly, the mean number of luminal leucocytes (Table 1) was greater for ovariectomized ewes than for either of the other groups $(P<0.01$ for each comparison). This indicated that ovarian hormones of both oestrous and luteal-phase ewes inhibited the leucocytic response. 
By $8 \mathrm{hr}$ the number of luminal leucocytes in ovariectomized ewes had nearly reached a peak and leucocytic migration from the vascular system was decreasing. The response in oestrous ewes was well developed, the number of luminal leucocytes approaching that of ovariectomized ewes (Table 1). Both tissue leucocytosis and numbers of luminal leucocytes were greater in oestrous than in luteal-phase ewes $(P<0.05$ for tissue leucocytosis; $P<0.01$ for luminal leucocytes). These comparisons showed that ovarian hormones of the luteal phase inhibited the leucocytic response to a greater degree than did those of oestrus.

\section{TABLE 1}

RELATIVE DEGREES OF ENDOMETRIAL LEUCOCYTOSIS AND NUMBERS OF LEUCOCYTES AND Escherichia coli FLUSHED FROM UTERI OF OVARIEGTOMIZED, OESTROUS AND LUTEAL-PHASE EWES AFTER EXPERIMENTAL INOCULATION*

\begin{tabular}{|c|c|c|c|c|c|c|c|}
\hline \multirow{2}{*}{$\begin{array}{c}\text { Endocrine } \\
\text { state of ewes }\end{array}$} & \multirow{2}{*}{$\begin{array}{c}\text { After } \\
\text { inocu- } \\
\text { lation } \\
(h r) \\
\end{array}$} & \multirow{2}{*}{$\begin{array}{l}\text { No. } \\
\text { ewes }\end{array}$} & \multirow{2}{*}{$\begin{array}{c}\text { Tissue } \\
\text { leuco- } \\
\text { cytosis }{ }^{-} \\
( \pm \text {s.E. })\end{array}$} & \multicolumn{2}{|c|}{ Luminal leucocytes } & \multicolumn{2}{|c|}{ E. coli } \\
\hline & & & & $\begin{array}{l}\log N_{0} . \\
( \pm \text { S.E. })\end{array}$ & $\begin{array}{c}\text { Antilog } \\
\text { (millions) }\end{array}$ & $\begin{array}{l}\log N_{o} \\
( \pm \text { S.E. })\end{array}$ & $\begin{array}{c}\text { Antilog } \\
\text { (millions) }\end{array}$ \\
\hline Ovariectomized & $\begin{array}{r}2 \\
4 \\
8 \\
16\end{array}$ & $\begin{array}{l}5 \\
5 \\
5 \\
5\end{array}$ & $\begin{array}{l}4 \cdot 0 \pm 0.95 \\
6 \cdot 8 \pm 0 \cdot 49 \\
5 \cdot 0 \pm 0.55 \\
4.2 \pm 0.73\end{array}$ & $\begin{array}{l}5 \cdot 74 \pm 0 \cdot 15 \\
7 \cdot 67 \pm 0 \cdot 25 \\
8 \cdot 23 \pm 0.04 \\
8 \cdot 35 \pm 0.07\end{array}$ & $\begin{array}{r}0.6 \\
46 \cdot 8 \\
170 \cdot 0 \\
224 \cdot 0 \\
\end{array}$ & $\begin{array}{l}8 \cdot 58 \pm 0 \cdot 24 \\
6 \cdot 37 \pm 0 \cdot 70 \\
5 \cdot 99 \pm 0 \cdot 49 \\
4 \cdot 92 \pm 0 \cdot 25\end{array}$ & $\begin{array}{r}380 \cdot 0 \\
2 \cdot 3 \\
1 \cdot 0 \\
0 \cdot 1\end{array}$ \\
\hline Oestrc & $\begin{array}{r}2 \\
4 \\
8 \\
16\end{array}$ & $\begin{array}{l}5 \\
5 \\
5 \\
5\end{array}$ & $\begin{array}{l}2.4 \pm 0.75 \\
4.4 \pm 0.40 \\
6.6 \pm 0.75 \\
5.6 \pm 1.03\end{array}$ & $\begin{array}{l}5.48 \pm 0 \cdot 14 \\
6.48 \pm 0.18 \\
8.01 \pm 0.05 \\
8 \cdot 31 \pm 0.22\end{array}$ & $\begin{array}{r}0.3 \\
3 \cdot 0 \\
102 \cdot 0 \\
204 \cdot 0\end{array}$ & $\begin{array}{l}9.00 \pm 0.06 \\
9.03 \pm 0.08 \\
7.85 \pm 0.65 \\
6.24 \pm 0.43\end{array}$ & $\begin{array}{r}1000 \cdot 0 \\
1070.0 \\
70.8 \\
1.7\end{array}$ \\
\hline Luteal & $\begin{array}{r}2 \\
4 \\
8 \\
16\end{array}$ & $\begin{array}{l}5 \\
5 \\
5 \\
5\end{array}$ & $\begin{array}{l}1 \cdot 6 \pm 0 \cdot 24 \\
2 \cdot 4 \pm 0 \cdot 24 \\
3 \cdot 6 \pm 1 \cdot 21 \\
7 \cdot 6 \pm 0.51\end{array}$ & $\begin{array}{l}5.44 \pm 0.13 \\
6.12 \pm 0.23 \\
7.52 \pm 0.09 \\
8 \cdot 17 \pm 0.11\end{array}$ & $\begin{array}{r}0 \cdot 3 \\
1 \cdot 3 \\
33 \cdot 1 \\
148 \cdot 0\end{array}$ & $\begin{array}{l}9 \cdot 11 \pm 0 \cdot 03 \\
9 \cdot 15 \pm 0 \cdot 04 \\
9 \cdot 14 \pm 0 \cdot 04 \\
6 \cdot 94 \pm 0 \cdot 35\end{array}$ & $\begin{array}{r}1290 \cdot 0 \\
1410 \cdot 0 \\
1380 \cdot 0 \\
8 \cdot 7\end{array}$ \\
\hline
\end{tabular}

* The mean inoculum per ewe was $717,000,000$ E. coli cells.

† Values represent relative degrees of tissue infiltration by polymorphonuclear leucocytes graded on a scale from 0 to $9 ; 0$ indicates no response and 9 indicates very heavy infiltration.

By $16 \mathrm{hr}$ the leucocytic response had developed to full intensity in the luteal-phase ewes (Table 1). Comparison of the leucocytic responses (Table 1) suggests that an intense response was delayed approximately 2 to $3 \mathrm{hr}$ in oestrous as compared to ovariectomized ewes, and was delayed considerably longer in luteal-phase ewes.

Ewes of the three endocrine states varied in the nature of the leucocytic infiltration of the endometrium. Polymorphonuclear leucocytes were diffused throughout the endometrial tissue in ovariectomized and luteal-phase animals. In oestrous ewes leucocytes accumulated immediately under the epithelial lining of the endometrium; relatively few were scattered through the remainder of the endometrial stroma. This could have been due to such factors as relatively large numbers of leucocytes leaving the circulation immediately beneath the epithelium in oestrous ewes or to leucocytes passing faster through the endometrial stroma and accumulating beneath the epithelium. 
Bactericidal action occurred in the uterine lumen of ewes in each endocrine state, but at different time intervals (Table 1). Statistical analysis of the numbers of $E$. coli flushed from the uterine lumen showed that most $E$. coli were killed significantly earlier in ovariectomized ewes than in oestrous ones $(P<0.01)$, and significantly earlier in oestrous ewes than in luteal-phase ones $(P<0 \cdot 01)$. Some bacterial multiplication occurred in both oestrous and luteal-phase ewes during the early hours after inoculation.

\section{RELATION OF LEUCOCYTIC RESPONSE TO BACTERICIDAL ACTIVITY}

The data show clearly that $E$. coli were killed as polymorphonuclear leucocytes entered the uterine lumens (Table 1). Correlation coefficients between log numbers of leucocytes and $E$. coli flushed from the uterus were significant over all sheep $(\mathrm{r}=-0.721 ; P<0.01)$ and among means of the twelve endocrine state-time interval subgroups $(\mathrm{r}=-0.899 ; P<0 \cdot 01)$. Correlation coefficients for the ovariectomized, oestrous and luteal-phase groups were $-0.865,-0.684$ and -0.634 , respectively. Each was highly significant $(P<0 \cdot 01)$. These three coefficients did not differ significantly from one another when compared by the ' $Z$ ' test (Snedecor, 1956).

Phagocytosis by neutrophilic leucocytes no doubt constituted the major defence of these sheep uteri against the $E$. coli. Large numbers of phagocytized $E$. coli were seen in ewes of each endocrine state, particularly during the phase of rapid leucocytic influx. During later stages of the response fewer bacteria were seen in the leucocytes; presumably the phagocytized bacteria had been digested beyond recognition.

Non-cellular bactericidal factors were undoubtedly present in the uteri of these ewes after the leucocytic responses developed; such factors were found previously in inflammatory exudates from sheep uteri (Hawk et al., 1961a). In rabbits, similar factors kill bacteria of some species, but the killed bacteria are probably cleared from the uterus by phagocytosis (Hawk, Turner \& Sykes, 1960b; Winter, Broome, McNutt \& Casida, 1960). The non-cellular factors appear to be derived mostly or entirely from polymorphonuclear leucocytes (Hawk, 1959; Winter et al., 1960); blood serum bactericidins apparently are not involved to a great extent in the endocrine-controlled uterine defences (Hawk, 1959; Broome, Lamming \& Woodbine, 1959a).

The numbers of live $E$. coli in uteri of ovariectomized ewes had been reduced considerably by $2 \mathrm{hr}$ after inoculation, but relatively few leucocytes had entered the uterine lumen. The possibility was considered that these uteri might normally contain substances which were bactericidal in nature but unrelated to the presence of leucocytes. To test this possibility, uterine horns from oestrous, luteal-phase and ovariectomized ewes were excised, inoculated with $E$. coli and incubated for $2 \mathrm{hr}$ in the body cavity of a sheep. Also, an equal volume of inoculum in a small test tube was incubated in the body cavity along with the excised horns. Four replicates were used.

The mean number of live $E$. coli recovered from excised ovariectomized 
sheep uteri was not significantly less than the other mean numbers (Table 2). These results failed to indicate clearly that non-cellular bactericidal substances were normally present in uteri of ovariectomized ewes. Bactericidal action was likely due primarily to intense leucocytic activity before bacterial multiplication began, but other possibilities cannot be ruled out.

TABLE 2

MILLIONS OF Escherichia coli ALIVE AFTER INCUBATION FOR 2 HR IN TEST TUBES AND EXGISED SHEEP UTERI

\begin{tabular}{c|c|c|c|c|c}
\hline \multirow{2}{*}{$\begin{array}{c}\text { No. } \\
\text { replicates }\end{array}$} & $\begin{array}{c}\text { Mean inoculum } \\
\text { (millions) }\end{array}$ & $\begin{array}{c}\text { Test } \\
\text { tube }\end{array}$ & $\begin{array}{c}\text { Ovariectomized } \\
\text { sheep uterus }\end{array}$ & $\begin{array}{c}\text { Oestrous } \\
\text { sheep uterus }\end{array}$ & $\begin{array}{c}\text { Luteal-phase } \\
\text { sheep uterus }\end{array}$ \\
\hline 4 & 655 & 702 & 513 & 646 & 645 \\
\hline
\end{tabular}

LEUCOGYTIG MIGRATION THROUGH THE ENDOMETRIUM

In experimentally-infected rabbit uteri, polymorphonuclear leucocytes migrated into the endometrial stroma earlier and initially in greater numbers in pseudopregnant than in ovariectomized rabbits; however, leucocytes appeared earlier in uterine lumens of the ovariectomized rabbits (Hawk et al., 1960a; Hawk, Turner \& Sykes, 1961b). One interpretation was that progestin inhibited the migration of extravasated leucocytes through endometrial stroma of the pseudopregnant rabbits. In the present study there was no discrepancy among ewes of the three endocrine states in the relationship between the intensity of leucocytic infiltration of the endometrium and numbers of leucocytes entering the uterine lumen (Table 1). There was thus no evidence by this criterion that progestin inhibited leucocytic migration through the sheep endometrium.

Broome, Winter, McNutt \& Gasida (1960) divided the total number of leucocytes responding to experimental infection in rabbit uteri into numbers in the endometrium and numbers in the uterine lumen. Higher percentages of total leucocytes were found in the endometrial tissue in pseudopregnant than in oestrous rabbits at $5,10,20$ and $40 \mathrm{hr}$ after inoculation. This was also interpreted as evidence of inhibition by progestin of leucocytic migration through the endometrium. In ewes in the present study, counts were made of the number of leucocytes in microscopic sweeps through the diameter of uterine cross-sections and approximate counts were made of the total number of leucocytes in the uterine tissues. These values were compared to the numbers of luminal leucocytes. In ewes of each endocrine state, a high proportion of the total number of uterine leucocytes was in the endometrium in the early stages of the leucocytic response. At later stages over $90 \%$ of the total leucocytes was in the lumen. There did not appear to be variation among endocrine states which could not be accounted for by variation in the time that intense leucocytic emigration began. Thus, by the criterion which Broome et al. (1960) used in rabbits, there was no indication that progestin inhibited leucocytic migration through endometrial stroma of the ewe. 
There was no doubt that in these ewes ovarian hormones affected the leucocytic response primarily by influencing the occurrence of massive leucocytic emigration.

\section{DISCUSSION}

These results showed definite effects of ovarian hormones on the leucocytic response to inflammatory stimuli in the sheep uterus. Leucocytic responses were inhibited to a considerable degree by ovarian hormones of oestrus and to a greater degree by ovarian hormones of the luteal phase.

These results indicate that ovarian hormones of oestrus affect the acute inflammatory response in the uterus in different ways in different species. Endogenous ovarian hormones hasten and intensify the acute response in oestrous rabbits and cattle (unpublished data from this laboratory), but inhibit it in oestrous sheep. Variation in hormonal balances or in tissue responses to hormones might be involved in the species differences during oestrus.

The acute leucocytic response in oestrous sheep is slower than in oestrous rabbits or cattle. This appears to be due primarily to the differing effects of ovarian hormones of oestrus.

The inhibitory effects of endogenous ovarian hormones on the acute inflammatory response in the ewe is probably restricted to the uterus. Leucocytic responses in experimentally-infected mammary glands were more intense initially in both oestrous and luteal-phase ewes than in ovariectomized ones (unpublished data from this laboratory). In rabbits, the ovarian status apparently did not influence the leucocytic response to induced infection in the peritoneal or pleural cavities (Hawk, Simon, Cohen, McNutt \& Casida, 1955; Hawk et al., 1960b).

Various possible mechanisms have been examined by which ovarian hormones might affect the leucocytic responses to inflammatory stimuli in the uterus. In rabbits, endocrine effects could not be accounted for by variation in numbers of circulating leucocytes or numbers of leucocytes normally present in uterine tissue (Broome et al., 1960). Cell-free inflammatory exudates from rabbit uteri induced leucocytic emigration and increased vascular permeability in rabbit skin, but the variations involved indicated that ovarian hormones influenced leucocytic responses in the uterus through mechanisms other than leucotaxic properties of uterine contents (Hawk et al., 1961b). Heparin given intravenously to rabbits did not change the endocrine effects on leucocytic emigration; thus there was no suggestion that blood-clotting mechanisms were involved (Hawk, Turner \& Brinsfield, 1963b).

Heap et al. (1962) suggested that progesterone might stimulate the presence in the uterine lumen of a substance which inhibits leucocytic infiltration. Lamming (1961) reported the sheep uterus to be resistant to induced uterine infection during the luteal phase of the oestrous cycle as well as during oestrus; this was related to the lack of an acid-soluble fraction in uterine flushings of the sheep. However, Lamming's results differ from the results presented in this report as well as from other results (Hawk et al., 1961a) in finding no endocrinecontrolled variation in sheep uterine defences.

Leucocytic emigration in the uterus may be related to endocrine control of 
endometrial vascular permeability (Hawk et al., 1963a; Hawk, Turner \& Brinsfield, 1963c).

\section{ACKNOWLEDGMENTS}

The authors are grateful to the Sheep and Fur Animal Research Branch, U.S.D.A., Beltsville, Maryland, U.S.A., for supplying the sheep used in this study.

Gratitude is expressed to $\mathrm{Mr} \mathrm{H}$. F. Righter for technical assistance during this study.

\section{REFERENCES}

Black, W. G., Ulberg, L. G., Kidder, H. E., Simon, J., MaNutt, S. H. \& Casida, L. E. (1953a) Inflammatory response of the bovine endometrium. Amer. F. vet. Res. 14, 179.

Black, W. G., Simon, J., MaNutt, S. H. \& CAsida, L. E. (1953b) Investigations on the physiological basis for the differential response of estrous and pseudopregnant rabbit uteri to induced infection. Amer. 7. vet. Res. 14, 318.

Black, W. G., Simon, J., Kmder, H. E. \& Wiltbank, J. N. (1954) Bactericidal activity of the uterus in the rabbit and the cow. Amer. 7. vet. Res. 15, 247.

Broome, A. W. J., Lamming, G. E. \& Woodbine, M. (1959a) Studies on the relationship between ovarian hormones and uterine infection. I. The effect of ovarian hormones on the bactericidal activity of blood plasma. 7. Endocrin. 18, 209.

Broome, A. W. J., Lamming, G. E. \& Smith, W. (1959b) Studies on the relationship between ovarian hormones and uterine infection. IV. The role of the granulocyte system in uterine defence. F. Endocrin. 19, 274.

Broome, A. W., Winter, A. J., MeNutt, S. H. \& Gasida, L. E. (1960) Variations in uterine response to experimental infection due to the hormonal state of the ovaries. II. The mobilization of leukocytes and their importance in uterine bactericidal activity. Amer. F. vet. Res. 21, 675.

Duncan, D. B. (1955) Multiple range and multiple F tests. Biometrics, 11, 1.

HAwK, H. W. (1958) The influx of leukocytes and presence of bactericidal substances in inoculated uteri of estrous and pseudopregnant rabbits. F. Anim. Sci. 17, 416.

HAwK, H. W. (1959) Investigations concerning bactericidal substances in rabbit uteri. Amer. J. vet. Res. 20, 206.

Hawk, H. W., Turner, G. D. \& Sykes, J. F. (1960a) The effect of ovarian hormones on the uterine defense mechanism during the early stages of induced infection. Amer. F. vet. Res. 21, 644.

Hawk, H. W., Turner, G. D. \& Sykes, J. F. (1960b) Noncellular bactericidal factors in inflammatory exudates from the uterine and pleural cavities of estrous and pseudopregnant rabbits. Amer. $\mathcal{J}$. vet. Res. 21, 657.

Hawk, H. W., Turner, G. D. \& Sykes, J. F. (1961a) Variation in the inflammatory response and bactericidal activity of the sheep uterus during the estrous cycle. Amer. F. vet. Res. 22, 689.

Hawk, H. W., Turner, G. D. \& Sykes, J. F. (196Ib) The leukotaxic properties of uterine exudates as related to the endocrine-controlled uterine defense mechanism. Amer. F. vet. Res. 22, 1117.

HAWK, H. W., Brinsfield, T. H. \& RighteR, H. F. (1963a) Control by ovarian hormones of vascular permeability in normal and experimentally-infected sheep uteri. F. Reprod. Fertil. 6, 71.

Hawk, H. W., TURNer, G. D. \& BRINSField, T. H. (1963b) Effect of heparin on hormonal control of leukocytic emigration in the rabbit uterus. Amer. F. vet. Res. 24, 352.

Hawk, H. W., TuRner, G. D. \& Brinsfield, T. H. (1963c) Endocrine control of vascular permeability and leukocytic emigration in the rabbit uterus. Amer. F. vet. Res. 24, 595.

Heap, R. B., Robinson, D. W. \& Lamming, G. E. (1962) The relationship between ovarian hormones and uterine infection in the rabbit. A possible mode of action. F. Endocrin. 23, 351.

Lamming, G. E. (1961) The influence of ovarian hormones on resistance to uterine infection. F. Reprod. Fertil. 2, 517.

McDonald, L. E., Black, W. G., McNutt, S. H. \& Casida, L. E. (1952) The response of the rabbit uterus to instillation of semen at different phases of the estrous cycle. Amer. F. vet. Res. 13, 419.

Rowson, L. E. A., LAmming, G. E. \& Fry, R. N. (1953) The relationship between ovarian hormones and uterine infection. Vet. Rec. 65, 335.

SNedecor, G. W. (1956) Statistical methods, 5th edn. Iowa State College Press, Ames.

Winter, A. J., Broome, A. W., MaNutt, S. H. \& CASIDA, L. E. (1960) Variations in uterine response to experimental infection due to the hormonal state of the ovaries. I. The role of cervical drainage, leukocyte numbers, and noncellular factors in uterine bactericidal activity. Amer. J. vet. Res. 21, 668. 